\title{
СУЧАСНА ДИТЯЧА ПЕРІОДИКА ЯК ЗАСІБ МОРАЛЬНОГО ВИХОВАННЯ ДІТЕЙ СТАРШОГО ДОШКІЛЬНОГО ВІКУ
}

in higher and secondary schools. Zaporizhzhia. No. 60, pp. $72-75$. [in Ukrainian].

5. Ksenofontova, L.S. (2014). Ispolzovanie videomateriala na urokakh fiziki [Use of video material in physics lessons]. [Electronic resource]. Moscov. Available at: https://nsportal.ru/shkola/fizika/ library/2014/12/04/ispolzovanie-videomateriala-naurokakh-fiziki [in Russian].

6. Pavelkiv, R.V. (2015). Vikova psykholohiia: pidruch. Vyd. 2-e, ster. [Age psychology]. Kyiv, 469 p. [in Ukrainian].

7. Piznavalnyi rozvytok u pidlitkovomu vitsi [Cognitive development in adolescence]. [Electronic resource]. Electronic library of Knyazev. Available at: http://www.ebk.net.ua/Book/synopsis/psyhologiya/ part2/021.htm [in Ukrainian].

8. Pustovoytov, V.N. (2002). Razvitie poznavatelnoy samostoyatelnosti uchashchikhsya starshikh klassov na urokakh matematiki i informatiki [Development of cognitive independence of students of senior classes in mathematics and computer science lessons]. Bryansk, 120p. [in Russian].

9. Khimiia. 7-9 klasy. Prohrama dlia zahalnoosvitnikh navchalnykh zakladiv (onovlena) (2017). [Chemistry. 79 classes. Program for general educational establishments]. (Ed.).Velychko L.P., Dubovyk O.A., Kotliar Z.V. (et al). MON Ukrainy vid 07.06.2017 no. 804. [in Ukrainian].

Стаття надійшла до редакції 27.03.2019

УДК 373.034(477)(091)

DOI:

Марія Кузьмич, магістр кафедри початкової та дошкільної освіти Львівського національного університету імені Івана Франка

\section{СУЧАСНА ДИТЯЧА ПЕРІОДИКА ЯК ЗАСІБ МОРАЛЬНОГО ВИХОВАННЯ ДІТЕЙ СТАРШОГО ДОШКІЛЬНОГО ВІКУ}

Стаття присвячена розгляу сучасної дитячої періодики як одного з засобів морального виховання дітей старшого дошкільного віку. Обтрунтовується, щчо періодичні видання значно швидие, ніж книжкові, зосереджуються на актуальних для дітей проблемах, а тому є надзвичайно дієвим засобом занурення у світ моральних иінностей та життя у динамічному соиіумі. А ие спонукає до формування у дитини стійких навичок літературного мовлення, спілкування на засадах поваги до себе та навколишнього світу, формує етичну культуру особистості.

Ключові слова: дитина дошкільник; моральне виховання; дитяча періодика; журнали для дошкільників. Jim. 6.

Mariya Kuzmych, Master of the Primary and Preschool Education Department Lviv Ivan Franko National University

\section{CURRENT CHILD'S PERIODICALS AS MEANS OF MORAL UPBRINGING OF CHILDREN OF SENIOR PRESCHOOL AGE}

The article is devoted to the consideration of modern child's periodicals as one of the means of moral education of children of the senior preschool age. The language of the children's edition is an extremely important structural and content component. It has its own means of expressiveness, efficiency, emotionality, and aesthetic ideals. The moral, intellectual, aesthetic development of children is directly related to spiritual enrichment. A huge role in the socialization of the person plays the word. The entry of a child into this universe occurs, first of all, with the help of a printed word, editions specially created for children.

Children's literature, periodicals nourish the mind and the imagination of the child, revealing new worlds, images and behavior patterns, is a powerful means of spiritual development of the individual. It is substantiated that periodicals are much faster than books, respond to events of the surrounding life, focus on urgent problems for children, and therefore it is an extremely effective means of immersion in the world of moral principles and life in a dynamic society. And this leads to the formation of stable skills in literary language in the child, communication on the basis of respect for themselves and the surrounding world, forms an ethical culture of the individual. The age-old special feature of preschoolers in the process of moral education through the means of periodicals is that children best remember the notion of morality, if they are presented in a form of play, with illustrative material, while not accepting large texts in volume.

Solving the tasks of moral education of children of the senior preschool age, the disclosure of his ideas is impossible outside of the language.

Keywords: a preschooler; moral upbringing; children's periodicals; magazines for preschoolers.

П остановка проблеми. Не зважаючи на сьогоденні економічні, духовні, видавничі негаразди світ української

дитячої преси активно розвивається. Гортаючи каталог передплати періодичних видань на друге півріччя 2018 року, можемо висновковувати, що в 
країні функціонує понад 100 видань дитячих журналів та газет всеукраїнського рівня. У переліку представлених на сьогоднішній день періодичних видань для дітей та молоді значний відсоток для дошкільнят.

Сучасна дитяча періодика задовольняє вимоги найпримхливішого читача. Тематична різноманітність і поліграфічна якість видань, яскравість та виразність художнього оформлення приваблюють дітей та їх батьків. Потрібно зауважити, що поряд із добре відомими не одному поколінню читачів журналів $є$ і зовсім сучасні видання, такі як “Малятко”, “Барвінок”, “Стежка”, “Пізнайко”, “Умійко”, “Зернятко”, "Професор Крейд”, “Колобочок”, “Смайлик”, “Колосок”. Це не обов'язково київські часописи, велика кількість періодичних видань $є$ надбаннями інших міст країни, зокрема "Куля”, “Колосок”, “Ангелятко” й “Ангеляткова наука” (Львів), “Дзвіночок” (Івано-Франківськ), “Зростаємо разом” (Харків), “Щедрику-ведрику” (Хмельницький), “Дитячий розвивайко” (Донецьк), “Новачок” і “Живе джерельце” (Черкаси) тощо.

Звісно, друкована продукція для дітей має бути не тільки якісною за змістом, але й за поліграфічним виконанням відповідати Галузевому стандарту України. Здійснений нами аналіз дитячої періодичної преси дає підстави для певних умовиводів та узагальнень щодо використання сучасної дитячої періодики як засобу морального виховання дітей старшого дошкільного віку.

Мета статті - окреслити можливості сучасної дитячої періодики як засобу морального виховання дітей старшого дошкільного віку.

Аналіз останніх досліджень і публікацій. В Україні проблема використання медіазасобів набула концептуального висвітлення в останні десятиліття здобутками багатьох науковців. Здебільшого дослідження стосуються проблем періодики для дітей як явища культурноісторичного життя в працях Т. Галковської, Т. Давидченка,К. Даценка, Т. СжижанськоїЛ. Круля, I. Крутя, Е. Огара, О. Орлика, Ю. Стадницької та iн.

Питання дитячої періодики як засобу розвитку мовленнєвої творчості досліджують О. І. Білан, Н. Вернигор, К. Даценко, О. Провоторов та ін.

Типологічну класифікацію дитячих періодичних видань запропонували Т. Давидченко, К. Даценко, Л. Круль, Т. Хітрова.

Медіа-психологічні проблеми сучасних дитячих видань аналізуються в працяхЮ. Бондаренко, Н. Кіт та ін.

Питання морального виховання особистості на різних етапах онтогенезу досліджувалася в працях українських учених в минулому та сьогоденні. Зокрема це дослідження I. Беха, Г. Васяновича, О. Вишневського, I. Зязюна, О. Кононко, М. Стельмаховича, В. Сухомлинського, Г. Шевченко та низки інших.

Виклад основного матеріалу. Дитячі періодичні видання є одним із засобів морального виховання дітей старшого дошкільного віку, адже, дозволяють продемонструвати їй моральноетичні норми та цінності, занурити дитину у світ соціокультурної дійсності.

3 педагогічної точки зору дитячі періодичні видання завжди були і залишаються важливими засобами дитячого простору та комунікації малюка зі світом дорослих. Дитячі часописи $\epsilon$ одним з важливих елементів виховання, навчання, розвитку, формування та соціалізації дошкільнят.

Сучасні дослідники дитячої періодики, зокрема T. Давидченко, пропонують класифікацію українських друкованих газет і журналів для дітей, в якій виокремлюють п'ять видів: пізнавальні, розважальні, навчальні, культурологічні, науковопопулярні [2].

До пізнавальних дитячих часописів відносяться всі видання, що мають переважно освітньо пізнавальний зміст. Тематика таких дитячих журналів та газет досить різноманітна. Більшість популярних серед дітей журналів та газет подають потрібну інформацію засобом гри, враховуючи, що гра - це природне заняття для дітей дошкільного віку. Досить часто редактори дитячих журналів намагаються донести до дитини інформацію упорядковано, створюючи тематичні журнали. У решті журналів чи газет такий матеріал подається вроздріб, що безперечно шкодить виданню, адже, ускладнює сприйняття дитиною потрібноїій інформації.

Усі пізнавальні видання досить чітко поділяються на два види, зокрема, енциклопедичні та ігрові. До ігрових належать - "Пізнайко", “Професор Крейд”, “Bratz-модница”, "Умійко”, “Веселые идейки”, “Малятко”, “Стежка”, “Ух малыш”, "Велика дитяча газета”. До енциклопедичних видань Т. Давидченко відносить ті видання, що представляють собою "маленьку енциклопедію" чи “маленькубібліотеку” [1]. У цікавій ілюстрованній формі в таких часописах розповідається про мистецтво, історію, природу, архітектуру. За своїм форматом це тонкі журнали. Їхньою особливістю $є$ наявність отворів для швидкозшивача, що дозволяе зберігати їх у спеціальній тематичній фірмовій теці. Цей вид видань представлений в Україні журналом - “Бібліотека журналу “Дивосвіт - казки, легенди, міфи” [1]. 


\section{СУЧАСНА ДИТЯЧАПЕРІОДИКА ЯК ЗАСІБ МОРАЛЬНОГО ВИХОВАННЯ ДІТЕЙ СТАРШОГО ДОШКІЛЬНОГО ВІКУ}

На сучасному ринку періодики для малюків дошкільного віку можна побачити багато видань розважального характеру, адже, діти люблять весело та цікаво проводити час, особливо це стосується дітей старшого дошкільного віку. Такі журнали - це здебільшого спосіб використати вільний час дитини, зацікавити іiі на деякий час коміксами або розмальовками. Це видання-газети - “Клякса", "Развлекайка", "Хатинка сканвордів”, журнали та газети коміксів "Комикс Симпсоны”, "Комикс: Marvel: команда", “Комикс: фантастическая четверка" тощо.

Журнали та газети розважального характеру можуть бути корисними для батьків, педагогів, вихователів, адже вони друкують корисний наочний матеріал, нові методики, сучасні форми ігор, вправ, тощо. Наприклад, допоможуть навчати основам англійської мови, математики, журнал може бути корисний при вивченні дошкільником абетки разом із батьками. Часто такі видання є двомовними (журналі матеріал подається різними мовами - українською і російською), або навіть тримовними (англійська, українська, французька). Розважальна періодика приваблює малюків приємними сюрпризами та подарунками, наприклад, наліпками, невеличкими іграшками до колекції тощо.

Навчальні видання можна умовно поділити ще на два види - освітні журнали і газети з уроками та релігійні. Освітні видання представлені журналами "Posnayko" для дітей віком від 4 років, що вивчають англійську мову, “Абетка”, “Абетка в картинках”, “Букварик”, “Буковинки-веселинки”, “Веселі уроки - jolly lessons", "Граємо в англійську”, “Математика в картинках” тощо.

Основа кожного номеру культурологічних видань - це художній матеріал, вітчизняна література, світова класика та фольклор. Вони чітко поділяються на два типи: літературнохудожні видання, де увага приділяється питанням літератури, друкується значна кількість художніх творів. Це журнали - “Яблунька”, “Джміль”, “В мире сказок”, “Соняшник”, “Котя”, “20 розмальовок”, “Чарівна казка”, тощо. В літературно-мистецьких виданнях, зокрема, у журналі "Веселочка", приділяється увага різним видам мистецтва, висвітлюються різноманітні культурні події в Україні та світі.

I. Круть пропонує класифікацію дитячих періодичних видань за ознаками: залежно від віку адресата, за характером інформації, за цільовим призначенням, за статтю, за регіоном розповсюдження. Залежно від віку адресата дитячих періодичних видань виділяють окрему категорію читачів, яких у видавничій практиці зазвичай позначають як діти дошкільного віку. Найпопулярнішими серед дошкільнят є такі журнали як “Ангелятко”, “Мамине сонечко”, "Пізнайко від 2 до 6" [4].

Зазвичай цільове призначення дитячого періодичного видання співпадає 3 його функціонально-тематичним спрямуванням та його визначає зміст. Це пізнавальні, розвивальні, розважальні часописи для задоволення потреб сучасних дітей. Пізнавальні - насичені інформаційно, більше 50 відсотків текстової інформації - про пригоди та світ тварин, рослин, життя та досягнення знаменитостей, наприклад, “Стежа”, “Барвінок”, “Професор Крейд”. Так, у журналах розвивального спрямування більшість інформації спрямована на розвиток різноманітних умінь і навичок у дошкільнят, на розвиток дрібної моторики та психічних процесів - уваги, пам'яті. Це значний відсоток матеріалів, що представлені у журналах "Пізнайко", “Мамине сонечко". Головна мета розважальних журналів, до цього виду відносимо видання, які мало насичені інформаційно, - відпочинок та розвантаження пізнавальної активності. Виділення цього виду $є$ певною умовністю, оскільки інформація, загалом, чомусь учить, щось розвиває, а, з іншого боку, усі матеріали для дітей - розважальні, мають цікаву та легку форму викладу. При виокремленні цього виду видань треба враховувати орієнтовну цільову аудиторію, адже, творча форма роботи 3 дошкільнятами виконуватиме також розвиваючу функцію.

3 огляду на статевий підхід виділяють журнали для хлопчиків (“Маленький розумник”), для дівчаток (“Маленька Фея”, “Чарівна Принцеса”, “Мокси/ Мохіе"). Нерозвиненою, на наш погляд, $\epsilon$ ланка регіональних, обласних журнальних видань. Журнал “Смайлик” поки що за поширенням можна вважати регіональним, але за характером інформації він регіон не презентує [5].

Усі засоби морального виховання молодших школярів на сторінках дитячих періодичних видань можна умовно поділили на вербальні, текстові, графічні, графічно-вербальні, мануальної праці. Причому в основі такого поділу розглядаємо текст, який в оперті на основні положення інформаційно-семіотичної концепції культури трактуємо як цілісність форми і змісту, певної інформації, вираженої відповідними знаками (слова людської мови, а також знаки штучних мов - фарби, лінії, ноти тощо) [4]. Їх конкретне сполучення створює знакову систему, що кодує і передає зміст ідеї морального виховання дітей дошкільного віку.

Мова дитячого видання $є$ надзвичайно 
важливим структурно-змістовим компонентом. Вона має свої засоби виразності, дієвості, емоційності, власні естетичні ідеали. Моральний, інтелектуальний, естетичний розвиток дітей безпосередньо пов'язаний iз ї духовним збагаченням. Величезну роль у соціалізації особистості відіграє слово. Входження дитини у світ моральних цінностей відбувається і за допомогою друкованого слова, видань, спеціально створених для малят. Дитяча література, періодичні видання живлять розум та уяву дитини, відкриваючи нові світи, образи та моделі поведінки, є могугнім засобом духовного розвитку особистості [1]. Словник, яким послуговуються автори при написанні дитячих творів, відповідає потребам лексикону дитини, ㄲï майбутньому життєвому, мовленнєвому досвіду.

Більшість понять морального виховання у змістовому наповненні часопису складають абстрактні іменники, наприклад, добро, зло, вірність, сумління тощо. У роботі з текстами періодичних видань слід враховувати, що дошкільник лише вчиться усвідомлювати значення абстрактних понять, на відміну від конкретних, а тому, не вміючи мислити абстрактними поняттями, співвідносити їх, дитина спирається у своїх поясненнях на конкретні приклади. У текстах дитячих періодичних видань використано саме таку схему. Абстрактне поняття морального виховання знаходить конкретне й реальне втілення удитячій свідомості.

У процесі морального виховання дітей дошкільного віку засобами періодичних видань слід також враховувати вікові особливості, а саме те, що діти найкраще запам'ятовують поняття моралі, якщо вони подані в ігровій формі, 3 ілюстративним матеріалом, при цьому вони не сприймають великі за обсягом тексти тощо.

Наприклад, у квітневому номері (2017 р.) журналу “Колобочок. Для розумних діточок” в основу казки Н. Книшової “Детективні пригоди кота Хитроуса” [3] покладено переказ однієї 3 “Дев’яти негідних речей, на презирстві до яких будується переконаність і емоційний світ морально порядної, духовно красивої людини", сформульованих В. Сухомлинським [6].

3'ясовуючи особливості мовного оформлення дитячої періодики, наголошуємо на тому, що мова дитячого видання - це особливий різновид літературної мови і вона має свої засоби виразності, дієвості, емоційності, свої етичні ідеали. Окрім того, засоби мови забезпечують ефективність комунікаційного процесу між часописом і читачем. Таким чином, вирішення завдань морального виховання дітей старшого дошкільного віку, розкриття його ідей неможливе поза мовою.

На думку Н. Вернигори, якщо періодичне видання підготовлено з урахуванням соціальних потреб і читацьких запитів сучасного маленького читача, зі знанням усіх рекомендацій психологів, педагогів, мовознавців, а також якщо редакційний колектив подбав про дотримання вимог стосовно розумових та психологічних характеристик конкретної вікової групи, то такі видання стануть постійним комунікативно-інформаційним каналом, що збагачує та розвиває цілісно особистість дитини, забезпечує безперервний зв'язок між навчальним та самоосвітнім процесами і вестиме маленького читача шляхом самовдосконалення [1].

Періодичне видання значно швидше, ніж книжкове, відгукується на події довколишнього життя, може зосереджуватися на актуальних для дітей проблемах, а тому є надзвичайно дієвим засобом занурення юних “читачів” у світ моральних засад та життя у динамічному соціумі. А це спонукає до формування у дитини стійких навичок літературного мовлення, спілкування на засадах поваги до себе та навколишнього світу, формує етичну культуру особистості.

Висновок. Засоби морального виховання дітей старшого дошкільного на сторінках дитячих періодичних видань можна умовно розділили на мовні, жанрові, графічні, графічно-вербальні, мануальної праці, тощо. Одиницями такого поділу $\epsilon$ змістове наповнення тексту. Це стилістичні особливості, морально-етична тематика, особливості художнього та публіцистичного матеріалу, вибір жанрів, використання художньообразних засобів, лексична база тощо.

Більшість усіх понять морального виховання складають абстрактні іменники, які конкретизують людські чесноти, наприклад, дружба, вірність, мудрість, доброта, справедливість, правда, тощо.

\section{ЛІТЕРАТУРА}

1. Вернигора Н. М. Роль періодичних видань для дітей у формуванні мовних навичок. URL: http:// journlib.univ.kiev.ua/index.php?act $=$ article \&article $=2052$.

2. Давидченко Т. С. Типологічна класифікація дитячих періодичних видань в Україні. Наукові записки інституту журналістики: науковий збірник / за ред. В. В. Різуна; КНУ імені Тараса Шевченка. Київ, 2008. T. 30. C. 116-120.

3. Колобочок. Для розумних діточок. Щомісячний пізнавальний журнал для дітей 3 - 9 років. № $1-12$. $2015.24 \mathrm{c}$.

4. Круль Л. М., Благун Н. М. Загальний огляд сучасної української дитячої періодики (жанрово-тематичне розмаїття). Актуальні проблеми слов'янської 
філології. Серія: Лінгвістика і літературознавство: зб. наук. пр. 2009. Вип. ХХ. С. 402-411.

5. Рудницька О.П. Українське мистецтво у полікультурному просторі: Навчальний посібник. Київ, $2000.208 \mathrm{c}$.

6. Сухомлинський В. О. Вогнегривий коник: казки, притчі, оповідання /Упоряд. іпередм. О.В. Сухомлинський. Київ, 2007. 200 с. : іл.

\section{REFERENCES}

1. Vernyhora, N. M. Rol periodychnykh vydan dlia ditei $\mathrm{u}$ formuvanni movnykh navychok [The role of periodicals for children in the formation of language skills]. Available at: http://journlib.univ.kiev.ua/index.php?act $=$ article \&article $=2052$. [in Ukrainian].

2. Davydchenko, T. S. (2008). Typolohichna klasyfikatsiia dytiachykh periodychnykh vydan v Ukraini [Typological classification of the children's periodicals in Ukraine]. Scientific notes of the Institute of Journalism: scientific collection. (Ed.).V. V. Rizun. Kyiv, Vol. 30, pp. 116-120.[in Ukrainian].
3. Kolobochok. Dlia rozumnykh ditochok. Shchomisiachnyi piznavalnyi zhurnal dlia ditei $3-9$ rokiv (2015).[Kolobochok For smart kids. Monthly Cognitive Magazine for Children aged 3-9]. No. 1-12. 24 p. [in Ukrainian].

4. Krul, L. M. \& Blahun, N. M. (2009). Zahalnyi ohliad suchasnoi ukrainskoi dytiachoi periodyky (zhanrovo-tematychne rozmaittia) [An overview of modern Ukrainian children's periodicals (genre and thematic diversity)]. Actual problems of Slavic philology. Series: Linguistics and Literature: A collection of scientific works. Vol. 20, pp. 402-411. [in Ukrainian].

5. Rudnytska, O.P. (2000). Ukrainske mystetstvo u polikulturnomu prostori: navchalnyi posibnyk [Ukrainian art in the multicultural space: tutorial]. Kyiv, 208 p. [in Ukrainian].

6. Sukhomlynskyi, V. O. (Ed.). (2007). Vohnehryvyi konyk: kazky, prytchi, opovidannia [Gunpowder grasshopper: fairy tales, parables, stories]. Kyiv, 200 words illustrated.

Стаття надійшла до редакції 15.04.2019

УДК 373.2.015.31:613

DOI:

Марина Орлова, аспірант кафедри соціальної роботи Національного університету “Чернігівський колегіум” імені Т.Г. Шевченка

\section{ОРГАНІЗАЦІЙНО-ПЕДАГОГІЧНІ УМОВИ ЗБЕРЕЖЕННЯ ЗДОРОВ'Я ДІТЕЙ ДОШКІЛЬНОГО ВІКУ}

У статті визначено та охарактеризовано організаиійно-педагогічні умови здоров 'язбереження дітей дошкільного віку. Теоретичний аналіз наукової літератури з окресленої теми дозволив визначити такі умови здоров'язбереження дітей дошкільного віку: поєднання засвоєння дітьми знань про власне здоров 'я, иіннісне ставлення до нього та формування здорового способу життя з руховою активністю дітей; використання в закладах дошкільної освіти сучасних здоров 'язбережувальних педагогічних технологій; взаємодія сім'ї та закладу дошкільної освіти щодо здоров 'язбереження дітей.

Ключові слова: здоров'я; здоров'язбереження; дитина дошкільного віку; рухова активність; заклад дошкільної освіти; сім'я; педагогічна технологія.

Jim. 5.

Maryna Orlova, Postgraduate Student of the Social Work Department Taras Shevchenko "Chernihiv Collegium" National University

\section{ORGANIZATIONAL AND PEDAGOGICAL CONDITIONS OF PRESERVING THE HEALTH OF PRESCHOOL CHILDREN}

The article highlights the problem of preserving the children's health as an important task of modern Ukrainian society. The health is a complicated phenomenon of global significance, which includes a complex of social, economic, biological, medical aspects and serves as an object of consumption, capital investment, individual and social value, a social phenomenon, dynamic, constantly associated with the physical and social environment. Another definition, adopted by the World Health Organization, is widely known: this is a state of complete physical, mental and social well-being and not merely the absence of disease and physical defects.

The organizational and pedagogical conditions of preserving health of children of preschool age are defined and characterized in the article. Theoretical analysis of the scientific literature on this topic allowed us to define the following terms of preserving preschool children's health: the combination of learning knowledge about their own health, the value of the attitude towards it and the formation of a healthy lifestyle with motor activity of children; the use of the modern pedagogical technologies of health preserving in the institutions of the preschool education; the interaction between the family and the establishment of early childhood education for preserving children's health. 